
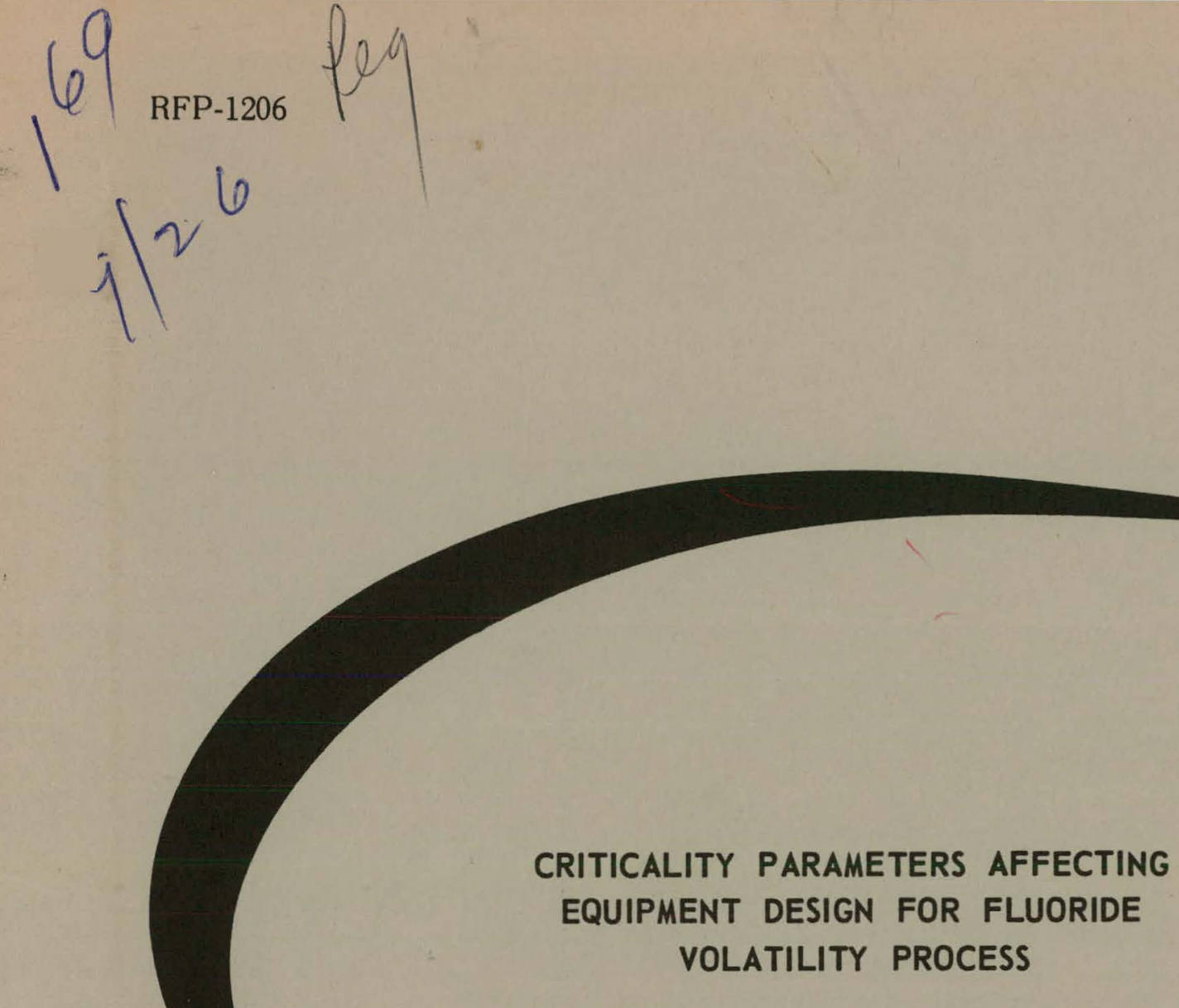

Donald R. Ferguson

C. Lee Schuske

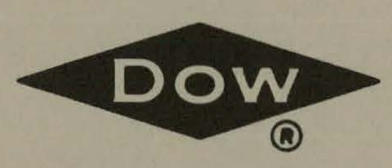

THE DOW CHEMICAL COMPANY

ROCKY FLATS DIVISION

P. O. BOX 888

GOLDEN, COLORADO 80401

U.S. ATOMIC ENERGY COMMISSION

CONTRACT AT(29-1)-1106. 


\section{DISCLAIMER}

This report was prepared as an account of work sponsored by an agency of the United States Government. Neither the United States Government nor any agency Thereof, nor any of their employees, makes any warranty, express or implied, or assumes any legal liability or responsibility for the accuracy, completeness, or usefulness of any information, apparatus, product, or process disclosed, or represents that its use would not infringe privately owned rights. Reference herein to any specific commercial product, process, or service by trade name, trademark, manufacturer, or otherwise does not necessarily constitute or imply its endorsement, recommendation, or favoring by the United States Government or any agency thereof. The views and opinions of authors expressed herein do not necessarily state or reflect those of the United States Government or any agency thereof. 


\section{DISCLAIMER}

Portions of this document may be illegible in electronic image products. Images are produced from the best available original document. 


\section{LEGAL NOTICE}

This report was prepared as an account of Government sponsored work. Neither the United States, nor the Commission, nor any person acting on behalf of the Commission:

A. Makes any warranty or representation, expressed or implied, with respect to the accuracy, completeness, or usefulness of the information contained in this report, or that the use of any information, apparatus, method, or process disclosed in this report may not infringe privately owned rights; or

B. Assumes any liabilities with respect to the use of, or for damages resulting from the use of any information, apparatus, method, or process disclosed in this report.

As used in the above, "person acting on behalf of the Commission" includes any employee or contractor of the Commission, or employee of such contractor, to the extent that such employee or contractor of the Commission, or employee of such contractor prepares, disseminates, or provides access to, any information pursuant to his employment or contract with the Commission, or his employment with such contractor.

Printed in the United States of America

Available from

Clearinghouse for Federal Scientific and Technical Information

National Bureau of Standards, U. S. Department of Commerce

Springfield, Virginia 22151

Price: Printed Copy $\$ 3.00$; Microfiche $\$ 0.65$ 


\title{
CRITICALITY PARAMETERS AFFECTING EQUIPMENT DESIGN FOR FLUORIDE VOLATILITY PROCESS
}

\author{
Donald R. Ferguson \\ C. Lee Schuske
}

\begin{abstract}
LEGAL NOTICE
This repnrt was prepared as an accounl of Government sponsored work. Nelther the United A. Makes any warranty or represerson acting on behalf of the Commlssion:

racy, completeness, or usefulness of of any information, apparatus, method or proceso donteined in this report, or that the use privately owned rights; or B. Assumes any

use of any information, apparatith respect to the use of, or for damages resulting from the As used in the above, "person acting or process disclosed in thits report. Dloyee or contractor of the Commlssion, or employee of such contractor, to the extent emdisseminates or providactor of the Comirasion, or employec of auch controctor prent that

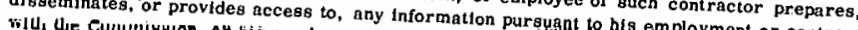
tilt dre Cutsumisulon, of his employment with such contractor.
\end{abstract}

\author{
THE DOW CHEMICAL COMPANY \\ ROCKY FLATS DIVISION \\ P. O. BOX 888 \\ GOLDEN, COLORADO 80401
}

U. S. ATOMIC ENERGY COMMISSION CONTRACT AT(29.1)-1106 
RFP-1206 


\section{CONTENTS}

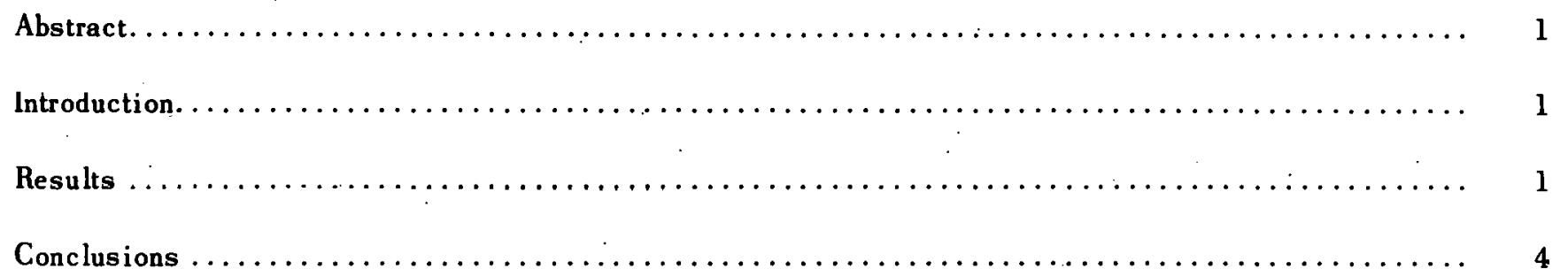


RFP-1206 


\title{
CRITICALITY PARAMETERS AFFECTING EQUIPMENT DESIGN FOR FLUORIDE VOLATILITY PROCESS
}

\author{
Donald R. Fergus on \\ C. Lee Schuske
}

\begin{abstract}
Discussed are various criticality parameters which may have an important influence on the design of fluoride volatility processing equipment.

The data presented may not have direct application to the design of a specific piece of process equipment. However by optimizing the various parameters discussed, in light of process requirements, the designer may provide a basis for a specific model.
\end{abstract}

\section{INTRODUCTION}

The design of large scale fluoride volatility processing equipment for plutonium is complicated by criticality considerations. Complications arise from at least two primary considerations. The fissile material is in the form of plutonium dioxide $\left(\mathrm{PuO}_{2}\right)$, plutonium tetrafluoride $\left(\mathrm{PuF}_{4}\right)$; and plutonium hexafluoride $\left(\mathrm{PuF}_{6}\right)$ which produces systems having a relatively hard neutron spectrum. Thus, such systems are difficult to control by means other than shape factor (ge ometry). In addition, during adverse conditions of processing, fusion of both or either $\mathrm{PuO}_{2}$ and $\mathrm{PuF}_{4}$ can occur and results in compound densities approaching crystalline densities. Because of these extreme density conditions, the designer of process equipment must consider restrictive vessel dimensions which limit the practicality of a design.

Discussed are several criticality parameters, such as the affects of density, moisture, personnel shielding, and geometry on critical mass and dimension. In addition, suggestions are given on how to minimize restrictions and provide practical dimensioned process equipment.

All given data were obtained from one dimensional, 16 grnup-transport calculations. The Hansen Roach Cross Sections are used in all calculations.

\section{RESULTS}

Tables I and II, and Figure 1 provide calculational data on the affect of shape, moisture, and density on the dimensions of infinite cylinders.

Table III and Figure 2 illustrate the advantage of putting an air gap between the process vessel and the reflector (biological shield). Caution should be exercised however in assuming full credit for this affect as restrictions would need to be imposed to preclude moving other amounts of fissile or reflecting materials (i.e., human hands) into the void space between the vessel and the reflector. TABLE 1. Critical Parameter for Water Re-
flected Infinite Cylinders of Plutonium
Dioxide and Plutonium Tetrafluoride.

Dry

Plutonium

Dioxide

Plutonium Dioxide

Atomic Ratio:

$\frac{\text { Hydrogen }}{\text { Plutonium }}=1$

Dry

Plutonium

Tetrafluoride

Plutonium

Tetrafluoride

Atomic Ratio:

Hydrogen $=1$

$\overline{\text { Plutonium }}=1$

\begin{tabular}{ccc} 
Plutonium & Infinite & Kilograms of \\
Density & Cylinder & Plutonium \\
(grams per & Diameter & per \\
cubic contimoter) & (inclics) & Lincar Fuó \\
\hline
\end{tabular}
cubic centimoter) (inclics) Lincér Fǘl

$\begin{array}{rrr}1.8 & 11.9 & 38.3 \\ 3.5 & 6.7 & 24.3 \\ 5.3 & 4.8 & 18.9 \\ 7.1 & 3.8 & 15.8 \\ & & \\ 3.5 & 6.0 & 19.7 \\ 5.3 & 4.3 & 15.3 \\ 7.1 & 3.5 & 13.0 \\ & & \end{array}$

$\begin{array}{lll}1.5 & 12.9 & 38.9\end{array}$

$\begin{array}{lll}3.0 & 7.2 & 24.4\end{array}$

$\begin{array}{lll}4.6 & 5.2 & 18.8\end{array}$

$\begin{array}{lll}5.3 & 4.6 & 17.1\end{array}$

$\begin{array}{lll}3.0 & 6.5 & 19.7\end{array}$

$\begin{array}{lll}4.6 & 4.6 & 15.2\end{array}$

$\begin{array}{lll}5.3 & 4.1 & 13.8\end{array}$ 
RFP-1206

TABLE II. Critical Parameters for Water Reflected Ten-Inch Inside Diameter Infinite Annuli of Plutonium Dioxide and Plutonium Tetrafluoride.

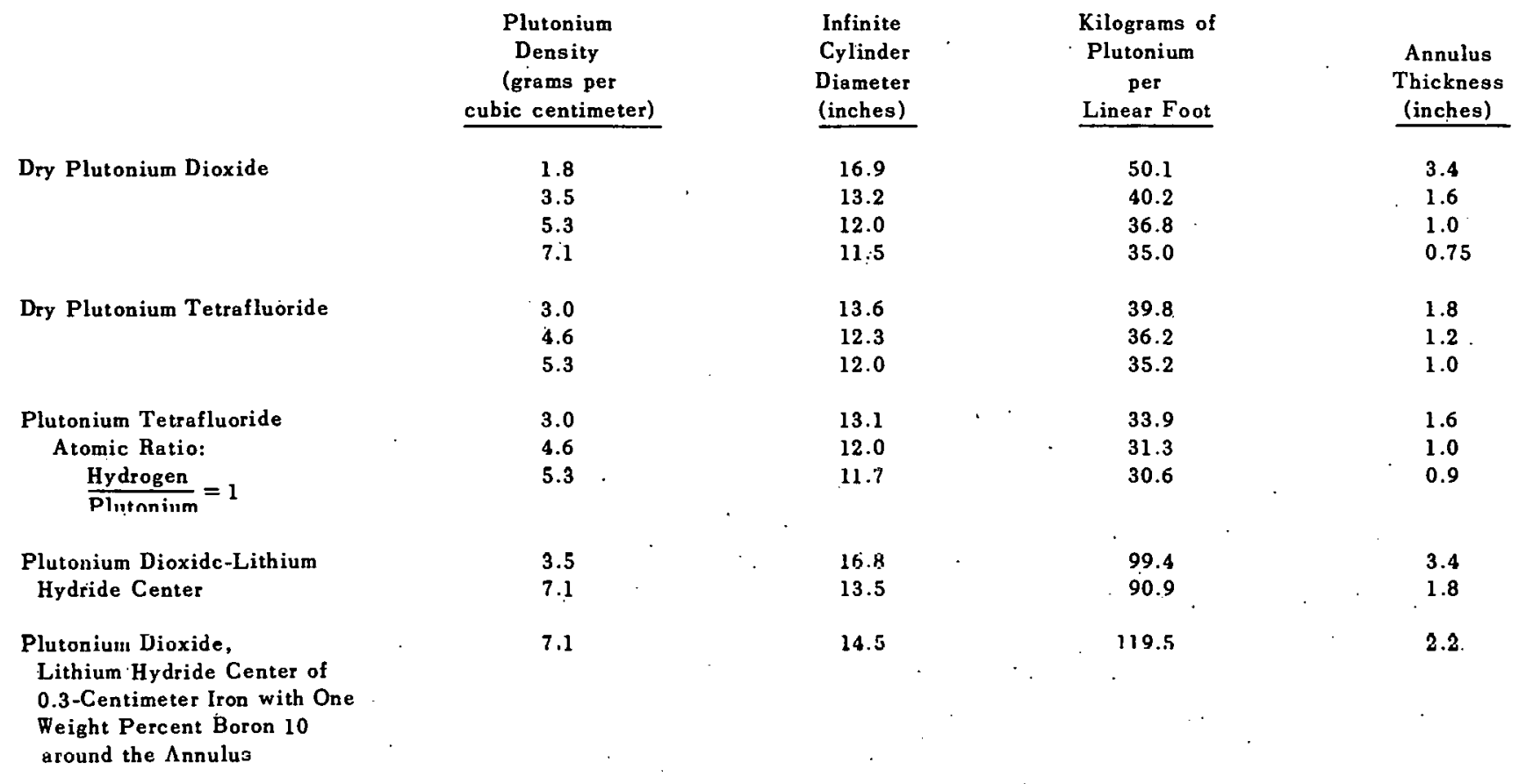

FIGURE 1. Affect of Moisture and Shape Factor on Criticality of Plutonium Dioxide.

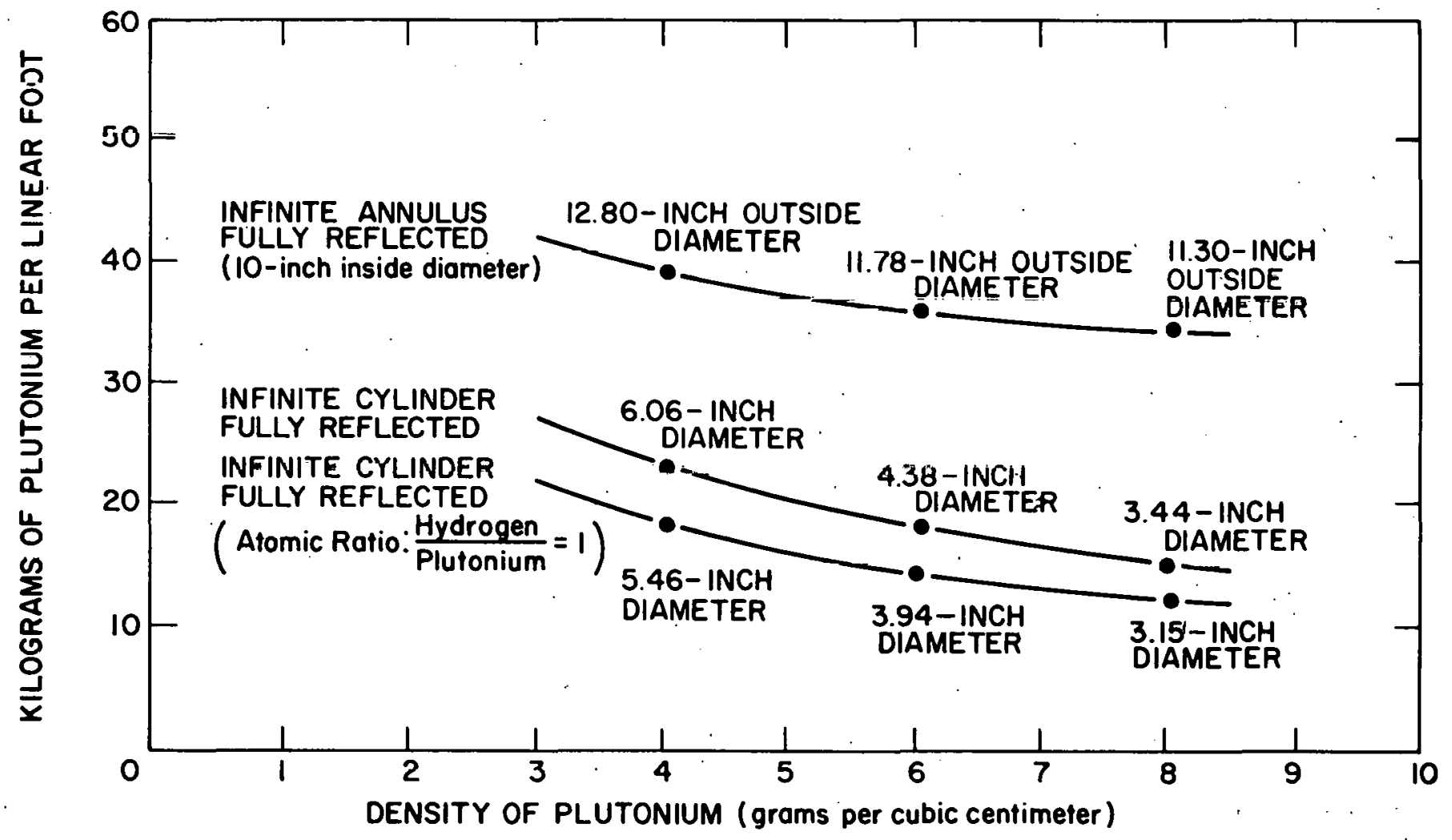


Figure 3 describes annular shaped vessels of infinite length with a 20-centimeter thick reflector. Each annular vessel described has a 10 -inch diameter hole running the full length of the annular cylinder. Reflection is considered to simulate a neutron shield

TABLE III. Critical Parameters for Water Reflected Infinite Cylinders of Plutonium Tetrafluoride with Voids between the Cylinder and Reflector.

Plutoniụm Dcnsity: 5.3 grams pèr cubic centimeter

\begin{tabular}{|c|c|c|}
\hline $\begin{array}{l}\text { Void } \\
\text { (inches) }\end{array}$ & $\begin{array}{l}\text { Infinite } \\
\text { Cylinder } \\
\text { Diameter } \\
\text { (inches') }\end{array}$ & $\begin{array}{c}\text { Kilogromo of } \\
\text { Plutonium } \\
\text { per } \\
\text { Linear Foot }\end{array}$ \\
\hline 0.0 & 4.6 & 17.1 \\
\hline 1.0 & 4.9 & 19.4 \\
\hline 0.0 & 5.8 & 22.9 \\
\hline 6.0 & 5.7 & 26.4 \\
\hline 12.0 & 6.1 & 30.7 \\
\hline 24.0 . & 6.5 & 35.1 \\
\hline
\end{tabular}

FIGURE 2. Affect of Air Gap on Criticality of Plutonium. Tetrafluoride.

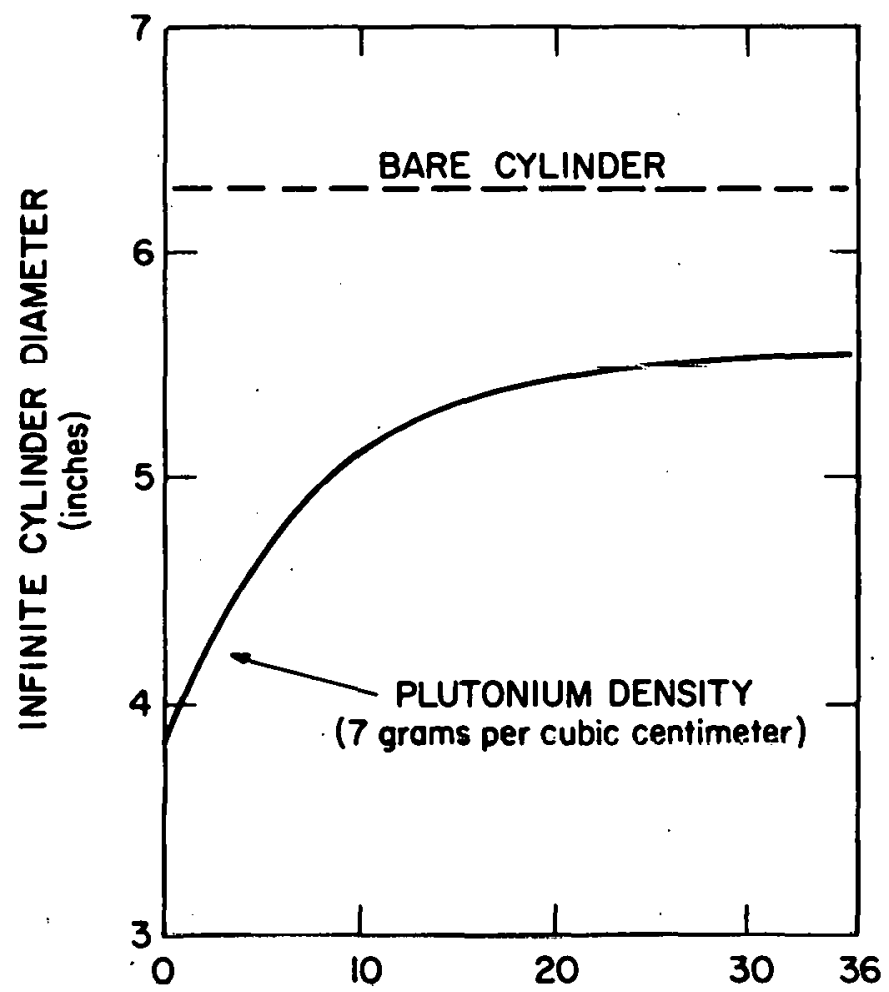

AIR GAP BETWEEN REFLECTOR AND CYLINDER (inches) used to protect operating personnel from neutrons produced by alpha-neutron reactions with fluorine.

Figure 3 and Table II illustrate the advantage of filling the 10-inch diameter hole with lithium hydride $\left({ }^{6} \mathrm{LiH}\right)$, as well as the addition of a boron-10 $\left({ }^{10} \mathrm{~B}\right)$ layer between the personnel shield and the annular vessel.

The 10-inch diameter was arbitrarily selected. Optimizing this parameter with process requirements could lead to a practical design.

FIGURE 3. Affect of Nuclear Poisons on Annular Thickness for Plutonium Dioxide.

\section{Legend}

1. Void Lenter.

2. Lithium-Hydride $\left({ }^{6} \mathrm{LiH}\right)$ Center.

3. Lithium-Hydride Center and Boron-10 Steel Shield.

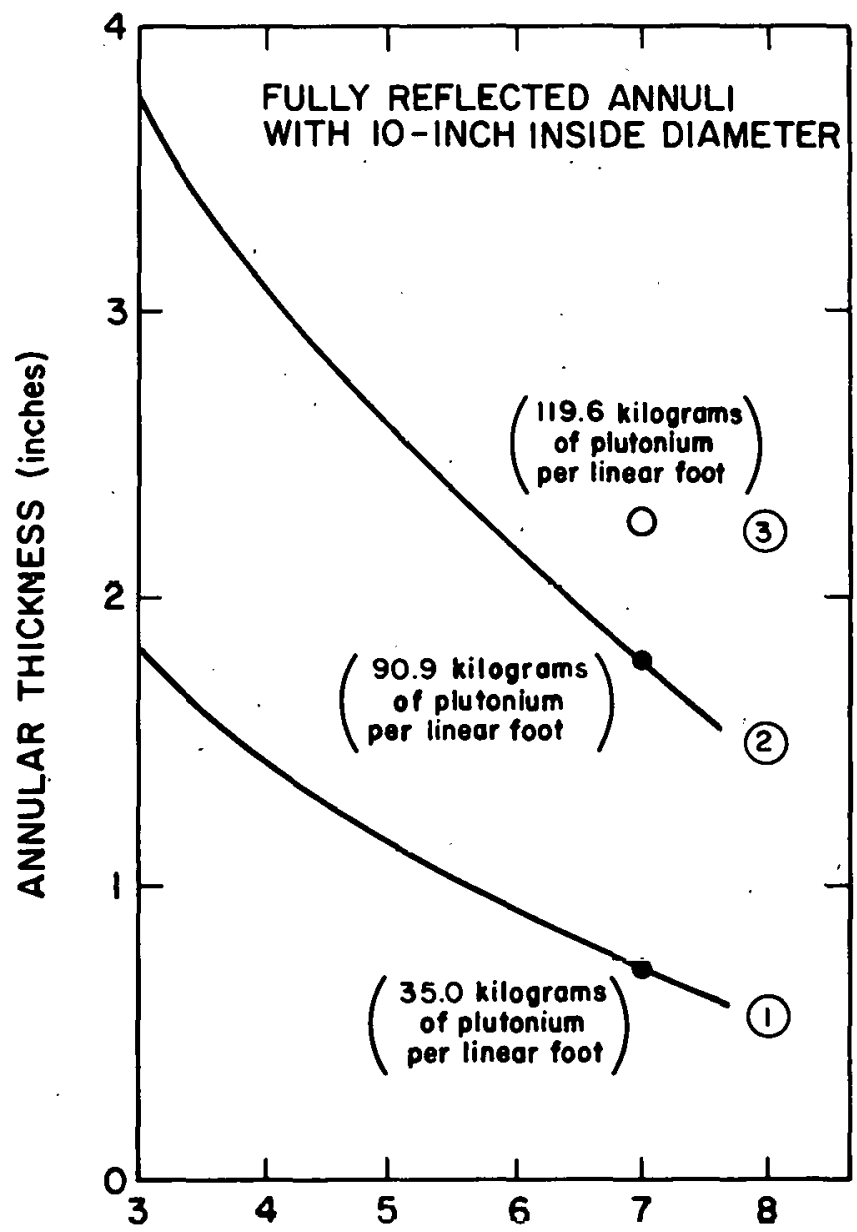

PLUTONIUM DENSITY (grams per cubic centimeter) 


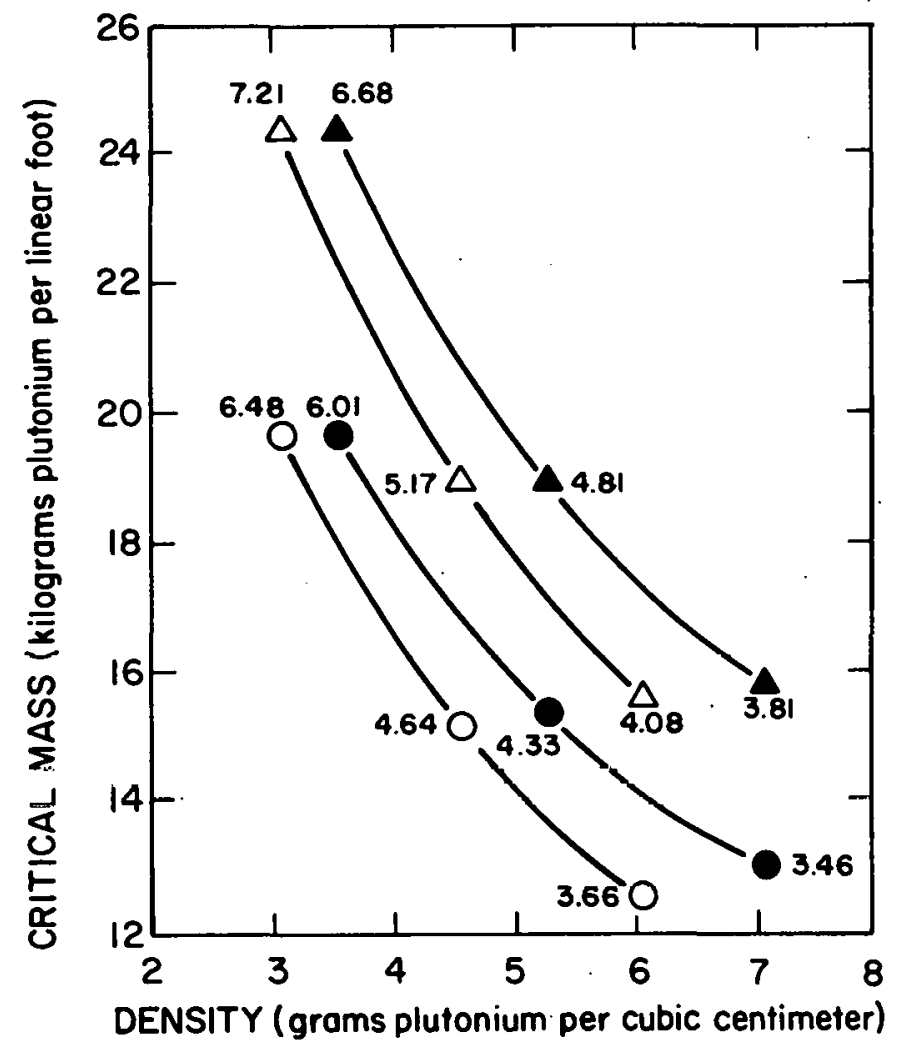

Legend

(Inch Dimensions: $6.48,4.64$, etc.)

Atomic Ratio: Hydrogen/Plutonium = 1

- Plutonium Tetrafluoride

- Plutonium Dioxide

Atomic Ratio: Hydrogen/Hlutonium $=0$

$\Delta$ - Plutonium Tetrafluoride

A - Plutonion Dioxide

FIGURE 4. Critical Water Reflected Infinite Cylinder.

TABLE IV. Critical Parameters for Infinite Cylinders of Plutonium Dioxide with Various Thicknesses of Reflector.

Plutonium Density: 7.1 grams per cubic centimeter

\begin{tabular}{ccc}
$\begin{array}{c}\text { Water Reflector } \\
\text { Thickness } \\
\text { (inches) }\end{array}$ & $\begin{array}{c}\text { Infinite } \\
\text { Cylinder } \\
\text { Diameter } \\
\text { (inches) }\end{array}$ & $\begin{array}{c}\text { Kilograms of } \\
\text { Plutonium } \\
\text { per } \\
\text { Linear foot }\end{array}$ \\
\hline 0.0 & 6.2 & \\
1.0 & 5.2 & 42.2 \\
2.0 & 4.3 & 28.9 \\
3.0 & 4.0 & 20.2 \\
4.0 & 3.8 & 17.1 \\
7.9 & 3.8 & 16.0 \\
& & 15.8
\end{tabular}

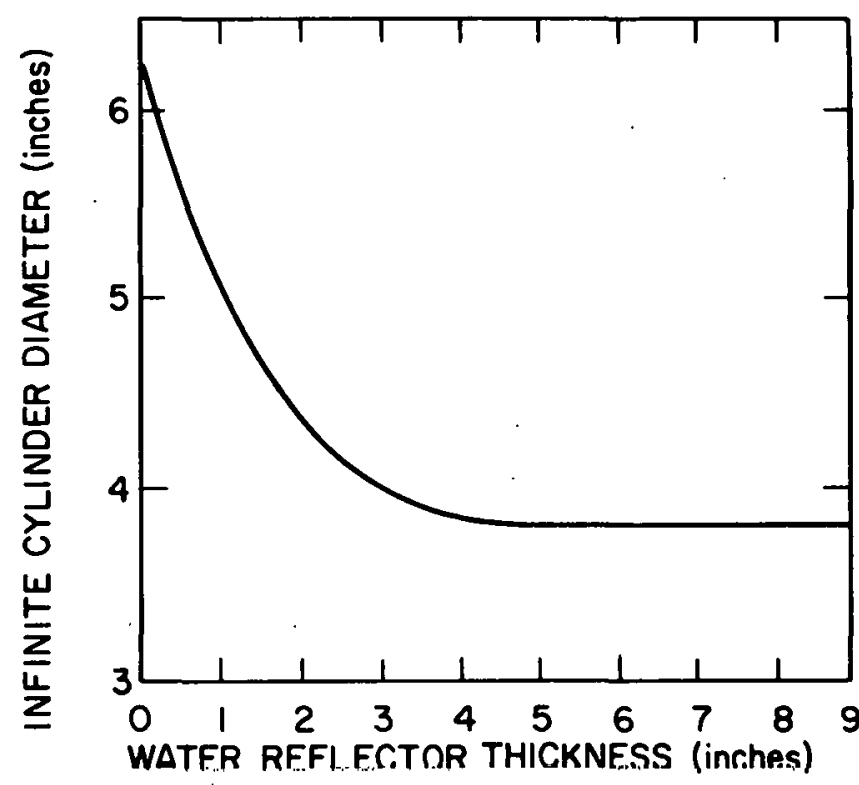

FIGURE 5. Critical Water Reflected Infinite Cylinders of Plutonium Dioxide.

Figure 4 and Table IV describe the affects of various thicknesses of water reflector as a function of a critical cylinder diameter.

Figure 5 shows the difference in critical cylinders. diameter for $\mathrm{PuF}_{4}$ and $\mathrm{PuO}_{2}$.

\section{CONCLUSIONS}

The data given indicate that if one must consider the possible occurrence of fused $\mathrm{PuO}_{2}$ and $\mathrm{PuF}_{4}$, considerable restriction to vessel dimensions could result.

In addition, due to excessive neutron flux produced by the alpha-neutron reaction on fluorine, personnel shielding is required. The amount of shielding required is a function of distance of nperating personnel to the process equipment, as well as the batch size of $\mathrm{PuF}_{4}$ to be handled. Some relief can be found by moving the shielding away from the immediate vicinity of the vessel. Care should be exercised to preclude using the void space between the fissile material and the neutron shield.

Thus, the combined use of nuclear poisons, inside as well as outside of an annular vessel, could result in a process vessel of practical dimensions. 